\title{
Effect of Dietary Protein Level on Growth and Body Composition of Juveniles Nile Perch (Lates niloticus, Linnaeus 1758)
}

\author{
Mouhamadou Amadou LY (Corresponding author) \\ Département Aquaculture, Université Gaston Berger \\ BP. 234 Saint-Louis, Senegal \\ Tel: 221-77-749-0165 E-mail: mamaly90@hotmail.com
}

Received: September 5, 2013 Accepted: September 20, 2013

doi:10.5296/jbls.v5i1.4225 URL: http://dx.doi.org/10.5296/jbls.v5i1.4225

\begin{abstract}
Nile perch (Lates niloticus, Linnaeus, 1758), is a carnivorous fresh water fish that have good market demand and suitable for aquaculture. The present study was designed to determine the effect of dietary protein level on growth and body composition of juveniles Nile perch. Five experimental diets with increasing levels of protein $(30,35,40,45$ and $50 \mathrm{~g}$ crude protein 100 $\mathrm{g}^{-1}$ feed) were prepared and fed in duplicate groups of Nile perch (initial weight : $8.67 \pm 0.17 \mathrm{~g}$ ) reared in ten $50 \mathrm{~L}$ tank for 8 weeks. Results showed that dietary protein level significantly influenced weight gain, specific growth rate and feed conversion ratio. The WG and SGR increased with increasing the protein level up to $45 \%$ content. Feed conversion ratio was lowest in Nile perch fed $45 \%$ protein and highest in those fed $30 \%$ protein. Fish fed with the $30 \%$ protein diet had the lowest survival and those fed $50 \%$ protein diet had the highest survival. There was no significant difference $(P>0.05)$ in Moisture among the dietary treatments. Protein and lipid showed linear increase as dietary protein levels increased. Fish fed diet $\geq 45 \%$ protein had the highest protein content, followed by fish fed 30 to $40 \%$ protein and lowest in the initial fish. Fish fed diet containing 50\% protein had the highest lipid carcass content, whereas the lowest lipid content among treatment was observed in the initial fish. Under the experimental conditions applied, juvenile L. niloticus, require $45 \%$ dietary protein for optimized growth.
\end{abstract}

Keywords: Nile perch, Lates niloticus, Protein levels, Growth 


\section{Introduction}

The Nile perch, Lates niloticus (Linnaeus, 1758), Family centropomidae, is a freshwater carnivorous fish of wide geographical distribution throughout the Ethiopian Region of Africa, occurring commonly in all major river basins including the Nile, Chad, Senegal, Volta and Congo. Most Lates niloticus in their natural environment feed on fish and insects (Goldschmidt et al., 1993; Ogutu-Ohwayo, 1993). Moreover, Nile perch is of great social economic importance in the East African region (Gumisiriza et al., 2009; Beuving, 2010). The Nile perch fishery is however under threat due to the intensive fishing pressure on the fishery that has resulted in a tremendous decline of its populations (Munyaho, 2004; Njiru et al., 2009). Current strategies for increasing Nile perch production point towards the culture of this species (Gregory, 2006). The culture development of this species will depend mainly on the availability of its seed and the development of well balanced and suitable feed.

Protein is the dietary macronutrient whose requirement is prioritized in nutritional studies, either because it represents the highest fish feed cost (Lovell, 1989; Fagbenro et al., 1992; Meyer and Fracalossi, 2005), or by greatly affecting fish weight gain (Martinez-Palacios et al., 2007; Zuanon et al., 2009), or needed for reproduction and survival of fish (Wilson and Halver, 1986).

In fish food, protein provides the essential and non essential amino acids to synthesize body protein and in part provides energy for maintenance (NRC, 1993; Kaushik and Médale, 1994). Feed constitutes $60-70 \%$ of total investment in intensive aquaculture. Any reduction in dietary protein level without affecting fish growth can substantially reduce the cost of fish feed (Fiogbé, 1996; Kim et al., 2003)

The determination of Lates niloticus nutritional requirements is essential for optimizing its aquaculture production. To our knowledge, data concerning the optimal dietary protein level for Lates niloticus juveniles have not been published. Given this lack of information on the basic nutrient requirements of this species, the present study has been undertaken to conduct experimentation with different protein level diets from $30 \%$ to $50 \%$ to determine growth performance and body composition of Lates niloticus juveniles.

\section{Materials and Methods}

\subsection{Experimental Conditions}

Wild Juvenile capitaine, Lates niloticus, weighing around $8.7 \mathrm{~g}$ at the beginning of the feeding trial were used in this study. These fish were obtained from a local fish dealer at the Diama dam, Saint- Louis, Senegal. Fish were acclimated to the experimental conditions for a period of two weeks. During this period, they were fed with a commercial catfish diet obtained from the National Aquaculture Agency hatchery located in Richard Toll district.

At the beginning of the experiment, fish were bulk-weighed and counted. Each experimental diet was randomly assigned to duplicate with 10 fish (mean weight: $8.67 \pm 0.17 \mathrm{~g}$ ) per glass tank. Water levels in each glass tank were maintained at $50 \mathrm{~L}$ and aerated constantly.

Experimental diets were hand-fed two times a day at 08:00 and 17:00 to apparent satiation, 
over a 30 -min period for 8 weeks.

Fish were subjected to a photoperiod of 12-h dark and 12-h light and all tanks had similar light conditions. Dissolved oxygen levels and water temperature were monitored daily and averaged $7 \mathrm{mg} / \mathrm{l}$ and $30^{\circ} \mathrm{C}$, respectively. Fish were bulk weighed every 2 weeks with fish being starved for $12 \mathrm{~h}$ prior to weight measurements and $12 \mathrm{~h}$ after. All aquaria were cleaned up every day in the morning by scrubbing and siphoning off accumulated waste materials. Each meal after feeding the uneaten food was removed manually to estimate food consumption.

\subsection{Experimental Diets}

Five experimental diets were formulated to contain graded level of protein from $30 \%$ to $50 \%$ in $5 \%$ increments. Fishmeal and shrimp meal were used as protein sources, fish oil as lipid source. Fishmeal and shrimp meal were finely grounded and poured through a sieve of $425 \mu \mathrm{m}$ mesh. Vitamin and mineral premix were mixed separately with the cellulose and the binder before being added to the main ingredient mixture. Diets were supplemented with fish oil after the addition of water (Table 1). The semi-moist mixture was then pressure pelleted in the food grinder using a $2 \mathrm{~mm}$ die, dried at $35^{\circ} \mathrm{C}$ for two days, cut to desired sizes, packaged into plastic bag and stored frozen until its usage. The diets were screened prior to feeding in order to remove the fines.

\subsection{Sampling and Analytical Methods}

At the beginning of the feeding trial, 10 fish were randomly sampled from the initial fish and at the end of the 8-week experiment 3 fish from each tank were sampled and all the sample are freeze-dried for subsequent proximate analyses.

The experimental diets and samples of the fish carcasses were analyzed for proximate composition according to the Association of Official Analytical Chemists: AOAC (1984) procedures. Crude lipid was determined by the ether extraction method by Soxtec System HT (Soxtec System HT6; Tecator); crude protein was determined with a Kjeltec system 1002 (Tecator), as describe by Mattisek et al., 1988 ; crude fiber was determined by the Fibertec system M 1020 hot extractor (FOSS Tecator) as describe by Folch et al., 1957 ; crude ash by incineration in a muffle furnace at $550^{\circ} \mathrm{C}$ for $24 \mathrm{~h}$, and dry matter by drying in an oven at $105^{\circ} \mathrm{C}$ for $24 \mathrm{~h}$;

Table 1. Formulation and proximate composition of the experimental diets of Nile perch (Lates niloticus).

\begin{tabular}{|lccccc|}
\hline Ingredients & $30 \%$ & $35 \%$ & $40 \%$ & $45 \%$ & $50 \%$ \\
\hline Fish meal & 32.9 & 37.7 & 42.5 & 47.3 & 52 \\
\hline Shrimp meal & 24 & 27.5 & 31 & 34,5 & 38 \\
\hline Fish oil & 6 & 6 & 6 & 6 & 6 \\
\hline Cellulose & 33.1 & 24.8 & 16.5 & 8.24 & 0 \\
\hline Binder & 1 & 1 & 1 & 1 & 1 \\
\hline Vit premix $^{\mathrm{a}}$ & 1 & 1 & 1 & 1 & 1 \\
\hline Min premix $^{\mathrm{a}}$ & 2 & 2 & 2 & 2 & 2 \\
\hline
\end{tabular}




\begin{tabular}{|lccccc|}
\hline Poximate composition $^{\mathrm{b}}$ \\
\hline Ash & 5.34 & 5.72 & 6.13 & 6.5 & 6.9 \\
\hline Crude protein & 32.3 & 36.6 & 42.4 & 47.1 & 51.5 \\
\hline Crude lipid & 9.98 & 10.51 & 11.05 & 11.58 & 12.12 \\
\hline Crude Fiber & 3.3 & 3 & 2.7 & 2.8 & 2.5 \\
\hline
\end{tabular}

${ }^{a}$ Vitamin premix and mineral premix as given in Lin and Shiau. (2003).

${ }^{\mathrm{b}}$ Values are presented in \% dry matter.

Several parameters were routinely monitored to ensure good water quality maintained. Water temperature and dissolved oxygen was measured everyday using YSI Model 58 oxygen meter (Yellow Springs Instrument, Yellow Springs, OH, USA). Water $\mathrm{pH}$ was measured everyday by pH tester DMT-30 Series.

\subsection{Calculations and Statistical Analysis}

Growth response parameters were calculated as follows: Weight gain $(\%)=100 *$ ( (final mean body weight - initial mean body weight)/ initial mean body weight); Specific Growth Rate $(\mathrm{SGR}, \% /$ day $)=100 *((\mathrm{In} \mathrm{Wt}-\mathrm{In} \mathrm{Wi}) / \mathrm{T})$, where Wt is the weight of fish at time t, Wi is the weight of fish at time 0 and $\mathrm{T}$ is the rearing period in days; Feed Conversion Rate $(\mathrm{FCR})=$ total dry feed fed $\mathrm{g}$ / fish / total wet weight gain $\mathrm{g} / \mathrm{fish}$. Survival rate $(\%)=100^{*}$ (number of fish which survived/initial number of fish).

Results are presented as mean \pm SEM. Data were subjected to one-way analysis of variance (ANOVA) to test the effect of 5 dietary protein levels as main effect. Treatment effects were considered significant at $P<0.05$; Duncan's new multiple range tests was used to compare significant difference among treatments. The survival data were transformed into a normal distribution using the arcsine square root prior to analysis of variance. All statistical analysis was carried out using the SAS/PC statistical software.

\section{Results}

During the experiment water temperature monitored ranged from 29 to $30^{\circ} \mathrm{C}$, dissolved oxygen content in the present experiment ranged from 5.5 to $7 \mathrm{mg} / \mathrm{l}$ and $\mathrm{pH}$ ranged from 7.5 to 8 .

Weight gain (WG), specific growth rate (SGR), feed conversion rate (FCR) and survival of Nile perch fed different diets are presented in Table 2. Weight gain and SGR were highest $(\mathrm{P}<$ 0.05 ) in Nile perch fed diets containing $\geq 45 \%$ protein, followed by $40 \%$ protein, then $35 \%$ group and lowest in fish fed with the $30 \%$ diet. The WG and SGR increased with increasing the protein level up to $45 \%$ content, but no further improvement was seen when dietary protein was increased to $50 \%$. Feed conversion ratio was lowest in Nile perch fed $45 \%$ protein and highest in those fed $30 \%$ protein. Fish fed with the $30 \%$ protein diet had the lowest survival and those fed $50 \%$ protein diet had the highest survival (Table 2). 
Table 2. Initial, final weight, weight gain, SGR, FCR and survival of Nile perch (Lates niloticus $)^{1}$

\begin{tabular}{|c|c|c|c|c|c|}
\hline \multicolumn{6}{|c|}{ Treatments } \\
\hline Parameters & $30 \%$ & $35 \%$ & $40 \%$ & $45 \%$ & $50 \%$ \\
\hline WG (\%) & $81.56 \pm 3.53^{\mathrm{d}}$ & $129.63 \pm 3.97^{\mathrm{c}}$ & $147.43 \pm 2.41^{\mathrm{b}}$ & $158.14 \pm 0.94^{\mathrm{a}}$ & $156.95 \pm 1.39^{\mathrm{a}}$ \\
\hline SGR & $1.06 \pm 0.03^{\mathrm{d}}$ & $1.48 \pm 0.03^{\mathrm{c}}$ & $1.62 \pm 0.02^{\mathrm{b}}$ & $1.69 \pm 0.01^{\mathrm{a}}$ & $1.69 \pm 0.01^{\mathrm{a}}$ \\
\hline FCR & $2.07 \pm 0.06^{\mathrm{a}}$ & $1.52 \pm 0.09^{\mathrm{b}}$ & $1.36 \pm 0.04^{\mathrm{cd}}$ & $1.24 \pm 0.03^{\mathrm{d}}$ & $1.45 \pm 0.05^{\mathrm{bc}}$ \\
\hline Survival (\%) & $70.00 \pm 14.14^{\mathrm{b}}$ & $75.00 \pm 7.07^{\mathrm{ab}}$ & $85.00 \pm 7.07^{\mathrm{ab}}$ & $85.00 \pm 7.07^{\mathrm{ab}}$ & $95.00 \pm 7.07^{\mathrm{a}}$ \\
\hline
\end{tabular}

${ }^{1}$ Values are means \pm standard deviation $(\mathrm{n}=2)$. Within a row, means with different superscript letters differ significantly $(P<0.05)$.

There was no significant difference $(\mathrm{P}>0.05)$ in Moisture among the dietary treatments. Protein and lipid showed linear increase as dietary protein levels increased. Fish fed diet $\geq 45 \%$ protein had the highest protein content, followed by fish fed 30 to $40 \%$ protein and lowest in the initial fish. Fish fed diet 50\% protein had the highest lipid content, whereas the lowest lipid content among treatment was observed in the initial fish (Table 3).

Table 3. Effect of dietary protein level on composition of whole body of Nile perch juveniles ${ }^{1}$

\begin{tabular}{|c|c|c|c|c|c|c|}
\hline \multicolumn{7}{|c|}{ Parameters } \\
\hline & Initial fish & $30 \%$ & $35 \%$ & $40 \%$ & $45 \%$ & $50 \%$ \\
\hline Moisture & $77.91 \pm 0.15$ & $77.74 \pm 0.19$ & $77.11 \pm 0.14$ & $77.51 \pm 0.11$ & $77.61 \pm 0.69$ & $77.35 \pm 0.07$ \\
\hline Protein & $51.49 \pm 0.36^{\mathrm{c}}$ & $52.55 \pm 0.21^{\mathrm{b}}$ & $52.52 \pm 0.30^{\mathrm{b}}$ & $52.91 \pm 0.15^{\mathrm{b}}$ & $54.61 \pm 0.08^{\mathrm{a}}$ & $54.76 \pm 0.06^{\mathrm{a}}$ \\
\hline Lipid & $11.24 \pm 0.09^{\mathrm{d}}$ & $12.22 \pm 0.14^{\mathrm{c}}$ & $13.32 \pm 0.38^{\mathrm{b}}$ & $13.51 \pm 0.04^{\mathrm{b}}$ & $13.76 \pm 0.08^{\mathrm{ab}}$ & $14.10 \pm 0.05^{\mathrm{a}}$ \\
\hline Ash & $20.09 \pm 0.16^{\mathrm{a}}$ & $20.33 \pm 0.24^{\mathrm{c}}$ & $20.85 \pm 0.07^{\mathrm{ab}}$ & $20.45 \pm 0.21^{\mathrm{bc}}$ & $20.28 \pm 0.73^{\mathrm{c}}$ & $20.26 \pm 0.17^{\mathrm{c}}$ \\
\hline
\end{tabular}

${ }^{1}$ Values are means \pm standard deviation $(\mathrm{n}=2)$. Within a row, means with different superscript letters differ significantly $(P<0.05)$.

\section{Discussion}

The present study is the first report to our knowledge regarding nutritional needs of Nile perch during the juvenile stage. It is well known that protein is the most important and expensive item of the feed that should be supplied in adequate amounts to support good growth with minimal cost (Wee and Tacon, 1982; Zehra and Khan, 2011). The development of the dietary protein level requirement for growth performance and body composition of juvenile Nile perch is a first step for better understanding of its nutritional states.

The current study showed significant effects of dietary protein level on growth performance of juvenile Nile perch. Weight gain and specific growth rate of fish were improved significantly with increasing dietary protein levels from $30 \%$ to $45 \%$. There were no difference between fish fed $45 \%$ and $50 \%$ protein and the best FCR was obtained with fish fed on diet containing $45 \%$ protein. This may be due to the increase in protein utilization and digestibility with the increase in dietary protein level up to $45 \%$. Based on these growth performance data, a $45 \%$ crude protein diet can be considered as the probable lower limit of the dietary protein range for good 
growth in Nile perch juveniles. As there are no previous published works on the protein requirement for Lates juveniles, it is difficult to compare the results obtained in this experiment. Our results are consistent with previous studies conducted on different species that weight gain and specific growth rate increased with dietary protein level increases up to an optimal level (Luo et al. 2004; Mohanty \& Samantaray 1996; Gunasekera et al. 2000; Yang et al. 2002). Arzel et al (1995) reported that the protein requirement for Salmo trutta to be between 48 to 53\%; Fiogbe and Kestemont (1995) reported 45-53\% for Carassius auratus. In general, carnivorous fish need 400-550 $\mathrm{g} \mathrm{kg}^{-1}$ dietary protein (Millikin 1983; Wilson and Halvar, 1986; Wilson 1989; NRC 1993; Kaushik, 1995; Chou et al. 2001).

Luo et al (2004) reported that optimal dietary protein requirement for E. coioides juveniles to be closed to $480 \mathrm{~g} \mathrm{~kg}^{-1}$ when fishmeal and casein were used as protein sources. Chen \& Tsai (1994) reported that E. malabaricus required $478 \mathrm{~g} \mathrm{~kg}-1$ dietary protein for maximum growth with casein as the protein source. Shiau \& Lan (1996) suggested that the dietary protein level that yielded maximum growth of E. malabaricus was $502 \mathrm{~g} \mathrm{~kg}^{-1}$ with fishmeal as a sole protein source. Lazo et al. 1998 reported that the optimal dietary protein requirement for Florida pompano to be $450 \mathrm{~g} \mathrm{~kg}^{-1}$.

The difference reported may be the results of different protein sources used, formulation methods, different fish sizes, differences between species, different environmental conditions, level of dietary intake and experimental duration.

In the present study, the best FCR was obtained with fish fed on diet containing $45 \%$ protein, the poorest FCR was observed in fish fed on diet having 30\% protein, but there was no significant difference between FCR obtained by 35, 40, 50\% protein diet. These results are in line with those of Wee \& Tuan, (1988) who reported that better FCR values were obtained with increasing dietary protein levels up to $42.5 \%$ and deteriorated slightly by diet containing $50 \%$ tilapia species. Florida pompano (2004) also showed that the best FCR were obtained at $45 \%$ protein level with Florida pompano.

The increase of dietary protein levels increased the whole-body protein deposition in Nile perch juveniles. This observation was in agreement with that reported for other fish species.

Ahmad et al (2012); Tidwell et al. (2005) and Pedro et al., (2001) reported the increase in carcass protein content with the increase in dietary protein level. This observation is in agreement with our findings. However, crude lipid contents of fish carcass significantly increased with increasing dietary protein level $(\mathrm{P}<0.05)$. The associated decrease in dietary carbohydrate levels in higher protein diets may be explained by metabolic changes towards an inhibition of the lipogenic pathway (Rema et al. 2008; Dias et al. 2004).

The survival rate of L. niloticus juveniles under different treatments ranged from 70 to $95 \%$ being $70 \%$ in fish feed containing $30 \%$ proteins. Some of the mortalities recorded were mainly due to the fish jumping out of the experimental tank despite the fact that the tanks were covered by a net.

In conclusion, our results indicate that diets for juvenile Lates niloticus containing $45 \%$ crude protein is recommended for better growth performance. 


\section{Acknowledgments}

The authors acknowledge the UGB Higher Education and Development project and the Gaston Berger University for their financial support in the execution of this work.

\section{References}

Ahmad, M., Qureshi, T. A., Singh, A. B., Susan, M., Kamlesh, B., \& Salman, R. C. (2012). Effect of dietary protein, lipid and carbohydrate contents on growth, feed efficiency and carcass composition of Cyprinus carpio communis fingerlings. International Journal of Fisheries and Aquaculture, 4(3), 30-40.

AOAC (Association of Official Analysis Chemists). (1984). Official Methods of Analysis, 14th edition, AOAC Arlington, VA, 1141pp.

Arzel, J., Metailler, R., Kereguer, C., Le Delliou, H., \& Guillaume, J. (1995). The protein requirement of brown trout (Salmo trutta) fry. Aquaculture, 130, 67-78. http://dx.doi.org/10.1016/0044-8486(94)00201-X

Beuving, J. J. (2010). Playing pool along the shore of Lake Victoria: Fishermen, careers, and capital accumulation in the Ugandan Nile perch business. Africa 80(2), 224-248. http://dx.doi.org/10.3366/afr.2010.0203

Chen, H. Y., \& Tsai, J. C. (1994). Optimal dietary protein level for the growth of juvenile grouper, Epinephelus malabaricus, fed semipurified diets. Aquaculture, 119, 265-271. http://dx.doi.org/10.1016/0044-8486 (94)90181-3

Chou, R. L., Su, M.-S., \& Chen, H.-Y. (2001). Optimal dietary protein and lipid levels for juvenile cobia (Rachycentron canadum). Aquaculture, 193, 81-89. http://dx.doi.org/10.1016/S0044-8486(00)00480-4

Dias, J., Rueda-Jasso, R., Panserat, S., Conceicao, L. E. C., Gomes, E. F., \& Dinis, M. T. (2004). Effect of dietary carbohydrate-to-lipid ratios on growth, lipid deposition and metabolic hepatic enzymes in juvenile Senegalese sole (Solea senegalensis, Kaup). Aquacult. Res., 35, 1122-1130. http://dx.doi.org/10.1016/S0044-8486(00)00480-4

Fagbenro, O. A., Balagon, A. M., \& Anyanwu, C. N. (1992). Optimum dietary protein level of Heterobranchus bidorsalis fed compounded diet. Nig. J. Appl. Fish. Hydrobiol., 1, 41-45.

Fiogbe, E.D., \& Kestemont, P. (1995). An assessment of the protein and amino acid requirements in goldfish (Carassius auratus) larvae. J. Appl. Ichthyol., 11, 282-289. http://dx.doi.org/10.1111/j.1439-0426.1995.tb00028.x

Folch, J., Lees, M., Stanley, \& G. H. S., (1957). A simple methods for the isolation and purification of total lipids from animal tissues. J. Biol. Chem., 226, 497-509

Goldschmidt, T., Witte. F., \& Wanink, J. (1993). Cascading Effects of the Introduced Nile Perch on the Detritivorous/Phytoplanktivorous Species in the Sublittoral Areas of Lake 
Victoria.

Conserv.

Biol.

$7(3)$

686-700.

http://dx.doi.org/10.1046/j.1523-1739.1993.07030686.x

Gregory, R. G. (2006). The Nile perch Lates niloticus: a potential candidate for cage aquaculture. In J. F. Halwart, FAO Regional Technical expert workshop on cage culture in Africa, Entebbe Uganda, 20th to 23rd October 2004. FAO Fisheries proceedings (Vol. No. 6). Rome: FAO.

Gumisiriza, R., Mshandete, A. M., Rubindamayugi, M. S., Kansiime, F., \& Kivaisi, A. K. (2009). Nile perch fish processing waste along Lake Victoria in East Africa: Auditing and characterization. Afr. J. Environ. Sci. Technol. 3(1), 013-020.

Gunasekera, R. M., De Silva, S. S., Collins, R. A., Goolley, G., \& Ingram, B. A. (2000). Effect of dietary protein level on growth and food utilization in juvenile Murray cod Maccullochella peelii peelii (Mitchell). Aquacult. Res., 31, 181-187. http://dx.doi.org/10.1046/j.1365-2109.2000.00417.x

Kaushik, S. J., \& Médale, F. (1994). Energy requirements, utilization and dietary supply to salmonids. Aquaculture, 124, 81-97. http://dx.doi.org/10.1016/0044-8486(94)90364-6

Kaushik, S. J. (1995). Protein nutrition and metabolism in fish. In: Protein Metabolism and Nutrition. Proceedings of the 7th International Symposium on Protein Metabolism and Nutrition, EAAP Publication 81 (Nunes, A.F., Portugal, A.V., Costa, J.P \& Ribeiro, J.R. eds), pp. 47-56. Wageningen Academic Publishers, Wageningen.

Kim, K., Wang, X., \& Bai, S. C. (2003). Reevaluation of the dietary protein requirement of Japanese flounder (Parlichthys olivaceus). J. World. Aquacult. Soc., 34(2), 133-139. http://dx.doi.org/10.1111/j.1749-7345.2003.tb00049.x

Lazo, J. P., Davis, D. A., \& Arnold, C. R. (1998). The effects of dietary protein level on growth, feed efficiency and survival of juvenile Florida pompano (Trachinotus carolinus). Aquaculture, 169, 225-232. http://dx.doi.org/10.1016/S0044-8486(98)00384-6

Lin, Y. H., \& Shiau, S. Y. (2003). Dietary lipid requirement of grouper, Epinephelus malabaricus, and effects on immune responses. Aquaculture, 225, 243-250. http://dx.doi.org/10.1016/S0044-8486(03)00293-X

Lovell, R. T. (1989). Nutrition and Feeding of Fish. Van Nostrand Reinhold, New York, USA, 260 pp. http://dx.doi.org/10.1007/978-1-4757-1174-5

Luo, Z., Liu, Y. J., Mai, K. S., Tian, L. X., Liu, D. H., \& Tan, X. Y. (2004). Optimal dietary protein requirement of grouper Epinephelus coioides juveniles fed isoenergetic diets in floating net cages. Aquaculture Nutrition, 247-252. http://dx.doi.org/10.1111/j.1365-2095.2004.00296.x

Martinez-Palacios, C., Ríos-Durán, M. G., Ambriz-Cervantes, L., Jauncey, K. J., \& Ross, L. G. (2007). Dietary protein requirement of juvenile Mexican Silverside (Menidia estor Jordan 1879), a stomachless zooplanktophagus fish. Aquacult. Nutr. 13, 304-310. 


\section{MlMacrothink}

Journal of Biology and Life Science ISSN 2157-6076 2014, Vol. 5, No. 1

Mattisek, R., Schnepel, F. M., \& Steiner, G. (1988). Lebensmittel Analytic. Springer, Berlin.44pp.

Meyer, G., \& Fracalossi, D. M. (2005). Estimation of Jundià (Rhamdia quelen) dietary amino acid requirements based on muscle amino composition. Sci. Agric. 62(4), 401-405. http://dx.doi.org/10.1590/S0103-90162005000400015

Millikin, M. R. (1983) Interactive effects of dietary protein and lipid on growth and protein utilization of age-0 striped bass. Trans. Am. Fish. Soc., 112, 185-193. http://dx.doi.org/10.1577/1548-8659(1983)112<185:IEODPA>2.0.CO;2

Mohanty, S. S., \& Samantaray, K. (1996). Effect of varying levels of dietary protein on the growth performance and feed conversion efficiency of snakehead Channa striata fry. Aquacult. Nutr., 2, 89-94. http://dx.doi.org/10.1111/j.1365-2095.1996.tb00013.x

Munyaho, A. T. (2004). Assesment of the status of the stock and fishery of Nile perch in Lake Victoria, Uganda. Final Project, Fisheries Training Programme. The United Nations University, Iceland.

Njiru, M., Getabu, A., Taabu, A. M., Mlaponi, E., Muhoozi, L., \& Mkumbo, O. C. (2009). Managing Nile perch using slot size: is it possible? Afr. J. Trop. Hydrobiol. Fish. 12, 9-14.

NRC (National Research Council., 1993). Nutrient Requirements of Fish. National Academy Press, Washington, DC, 114 pp.

Ogutu-Ohwayo, R. (1993). The effects of predation by Nile Perch, Lates niloticus L., on the fish of Lake Nabugabo, with suggestions for conservation of endangered endemic cichlids. Conserv. Biol. 7(3), 701-711. http://dx.doi.org/10.1046/j.1523-1739.1993.07030701.x

Pedro, N. D., Guijarro, A. I., Delgado, M. J., Patina, L. P., Pinillos, M. L., \& Bedate, M. A. (2001). Influence of dietary composition on growth and energy reserves in tench, Tincta ticta. $\begin{array}{lllll}\text { Journal of } \quad \text { Applied } & \text { Ichthyology, } & \text { 25-29. }\end{array}$ http://dx.doi.org/10.1046/j.1439-0426.2001.00274.x

Rema, P., Conceicao, L. E. C., Evers, F., Castro-Cunha, M., Dinis, M. T., \& Dias, J. (2008). Optimal dietary protein levels in juveniles Senegalese sole (Solea senegalensis). Aquaculture nutrition, 14, 263-269. http://dx.doi.org/10.1111/j.1365-2095.2007.00527.x

Shiau, S. Y., \& Lan, C. W. (1996). Optimum dietary protein level and protein to energy ratio for growth of grouper (Epinephelus malabaricus). Aquaculture, 145, 259-266. http://dx.doi.org/10.1016/S0044-8486(96)01324-5

Tidwell, J. H., Coyle, S. D., Bright, L. A., \& Yasharian, D. (2005). Evaluation of plant and animal source proteins for replacement of fish meal in practical diets for the largemouth bass, Micropterus salmoides. Journal World Aquaculture Society, 36, 454-463. http://dx.doi.org/10.1111/j.1749-7345.2005.tb00393.x

Wee, K. L., \& Tuan, N. A. (1988). Effects of dietary protein level on growth and reproduction in Nile tilapia (Oreochromis niloticus). ICLARM Conference Proceedings, 15, 623 


\section{Macrothink}

Wee, K. L., \& Tacon, A. G. J. (1982). A preliminary study on the dietary protein requirement of juvenile snakehead (Channa micropeltes). Bull. Jap. Soc. Sci. Fish., 48, 1463-1468. http://dx.doi.org/10.2331/suisan.48.1463

Wilson, R. P. (1989). Amino acids and proteins. In: Fish Nutrition, 2nd edn. (Halver, J.E. ed.), pp. 112-153. Academic Press, New York.

Wilson, R. P., \& Halver, J. E. (1986). Protein and amino acid requirements of fishes. Annu. Rev. Nutr. 6, 225-244. http://dx.doi.org/10.1146/annurev.nu.06.070186.001301

Yang, S. D., Lin, T. S., Liou, C. H., \& Peng, H. K. (2003). Influence of dietary protein level on growth performance, carcass composition and liver lipid classes of juvenile Spinibarbus hollandi (Oshima). Aquacult. Res., 34, 661-666. http://dx.doi.org/10.1046/j.1365-2109.2003.00880.x

Zehra, S., \& Khan, M. A. (2011). Dietary protein requirement for fingerling Channa punctatus (Bloch), based on growth, feed conversion, protein retention and biochemical composition. Aquacult. Int., 20(2), 383-395. http://dx.doi.org/10.1007/s10499-011-9470-8

Zuanon, J. A., Salaro, A. L., Moraes, S. S., Alves, L. M., Balbino, E. M., \& Araujo, E. S. (2009). Dietary protein and energy requirements of juvenile freshwater angle fish. R. Bras. Zootec. 38(6), 989-993. http://dx.doi.org/10.1590/S1516-35982009000600003

\section{Copyright Disclaimer}

Copyright reserved by the author(s).

This article is an open-access article distributed under the terms and conditions of the Creative Commons Attribution license (http://creativecommons.org/licenses/by/3.0/). 